\title{
TRADUZINDO A METÁFORA DA DANÇA EM RUMI
}

\author{
TRANSLATING DANCE METAPHOR IN RUMI
}

\section{Leandra Elena Yunis ${ }^{1}$}

\begin{abstract}
Resumo: 0 presente artigo apresenta uma tradução direta inédita do persa para o português de um gazal de Jalaluddin Rumi, poeta e místico persa do século XIII, fundador da Ordem dos Dervixes Rodopiantes de Konya. Nossa metodologia de análise e tradução utiliza de forma inovadora elementos de linguagem da Dança para explorar aspectos importantes da metáfora da dança na poesia sufi.
\end{abstract} Palavras-chave: Poesia persa, islã medieval, oriental dance, translation. sufismo, dança oriental, tradução.

\begin{abstract}
This article presents an unpublished translation, directly from Persian to Portuguese, of a ghazal by Jalaluddin Rumi, the great poet and mystical master of the 13th century and founder of the Mevlevi Order of the Whirling Dervishes of Konya. In an innovative way, our translation methodology uses elements of Dance language to explore aspects of dance imagery is sufi poetry.
\end{abstract}

Key-words: Persian poetry, medieval Islam, Sufism,

\section{Introdução}

Durante o mestrado (Yunis, 2013), analisei e traduzi a metáfora da dança em Rumi e Hafiz utilizando certos parâmetros e elementos da linguagem da Dança. 0 objetivo, na ocasião, era abordar a interação entre poesia, dança e audição mística, verificando o modo como determinados recursos da composição poética propiciam a reinstalação referencial da dança no ouvinte. No presente artigo apresentarei a tradução comentada de um poema de Jalal Uddin Rumi, poeta, dançarino e mestre místico do século XIII, fundador a Ordem Mevlevi dos Dervixes Rodopiantes de Konya. Na contramão do fanatismo religioso e de estereótipos orientalistas, Rumi é, a meu ver, um exemplo positivo e transhistórico de líder islâmico pacifista, visto que fomenta a guerra santa no sentido puramente místico; isto é, do aprimoramento interior que conecta o ser humano à divindade através da beleza e do amor universal ao próximo e à natureza (Teixeira, 2016: 163-168). Desta ótica, o nosso maior inimigo habita dentro de nós mesmos e só pode ser combatido através da pureza de coração e do autodomínio, como o que requer daqueles que dançam, entram na arena e

\footnotetext{
${ }^{1}$ Bacharelado e licenciatura em História (2001), mestrado em Língua, Literatura e Cultura Árabe (2013) e doutorado (em andamento) em Estudos Judaicos e Árabes, pela USP; é atual bolsista demanda social do CAPES sob orientação de Michel Sleiman. Pesquisadora, professora e dançarina de tradições árabes, persas e ciganas há 18 anos com especialização em Dança e Consciência Corporal pela FMU. E-mail: leyunis@gmail.com e CV Lattes: http://lattes.cnpq.br/5525960104590854
} 
marcham; dançam no próprio sangue e encorajam (Rumi [1207-1273], 1940), ${ }^{2}$ como se lê no Masnavi, o "corão persa".

Antes do Masnavi, obra teosófica de maturidade, Rumi compôs o Divan de Shams de Tabriz, extenso poemário lírico à Shams (nome que significa "sol"), seu próprio mestre, o dervixe errante que o iniciara através de uma ligação profunda e misteriosa (Guilhon, 2015). Boa parte dos versos deste livro foi recitada enquanto o poeta dançava em êxtase, dentre os quais se apresenta aqui a tradução do gazal 2131, cujas peculiaridades compositivas se apresentam como fortes indícios da estreita interrelação entre gesto, palavra e transe extático dessa obra lírica. Antes, porém, se faz necessário circularmos brevemente por alguns tópicos importantes a respeito do fenômeno coreográfico que se compartilha entre corpo e imagem poética na metáforica da dança.

\section{A dança muito além do aspecto motor}

Inspirada na proposta cognitiva de Raymond Gibbs e Nicole Wilson (2007), segundo a qual o gesto sintetiza ideias abstratas e especifica-lhes o sentido em função da atividade conjunta do córtex-motor com o pré-motor, ligado também à função imaginativa no cérebro, nossa metodologia de tradução e análise consiste numa espécie de gestalt tradutória que utiliza o movimento corporal para a apreensão do sentido poético. Uma vez que "a compreensão de muitas palavras e frases envolve a reinstalação parcial de experiências do indivíduo com o seu referente mundano real.,", toda referência poética à dança pode conduzir o ouvinte a reconhecer padrões de movimentação coreográfica e senti-los como atuando em si mesmos. Isso porque a representação imaginária da dança se dá de modo análogo ao efeito estético direto da sua representação imediata, visto que a arte coreográfica consiste, segundo Judith Lynne Hanna, na transformação simbólica da experiência humana através do encadeamento conjunto dos aspectos fisiológicos, musculares e neurais, afetando igualmente a plateia em termos motores, afetivos e cognitivos (Hanna, 1979: 19-28).

0 elemento definidor da linguagem da dança, seja em termos de tradição ou de criação livre, ${ }^{4}$ é o elemento coreográfico, constituído basicamente de propósito, intencionalidade rítmica e atividade motora. A significação coreográfica, porém, adquire sentido basicamente através de três aspectos fundamentais: o aspecto cultural (Williams, 2004: 168), que chamamos de extracinético e que permite que todos acessem ao menos

\footnotetext{
${ }^{2}$ M. III: 96. Tradução nossa.

3 "Recent empirical and theoretical advances in cognitive sciences suggest that understanding many words and phrases involves some partial reinstallation of one's experiences with its real-world referent". (Gibb e Wilson, 2007: 723).

${ }^{4}$ Do nosso ponto de vista, não há campo de criação puramente livre, pois mesmo as modalidades consideradas artísticas ou cênicas, contém convenções; é o caso mesmo da dança contemporânea ocidental, cuja universalidade é meramente ideológica. Por outro lado, toda tradição tem espaço para o improviso, de modo que há sempre, em maior ou menor grau, uma combinação de ambos elementos; ainda quando se trata de coreografia pré-estabelecida, há uma margem mínima de interpretação que permite identificar o talento criativo particular de cada dançarino.
} 
um significado coletivo ou pré-estabelecido para gestos e padrões coreográficos (o deslocamento em roda na ciranda, por exemplo); o aspecto cinético, relativo ao movimento das partes do corpo, à qualidade tônica ou motora da ação; e o aspecto metabólico, que envolve ritmo, intensidade e expressividade. Através da realização coreográfica, o movimento corporal tende a integrar também crivos de ordem moral, intelectual, existencial, histórico (Lopez y Royo, 2008), político e ideológico (Shay, 2002); essa espécie de processo-discurso, porém, funciona de modo relativamente aberto e é completado pela interação com a plateia. Ao ultrapassar o caráter lúdico e rítmico ou meramente ornamental e descritivo (pantomima) da dança, essa interação permite, eventualmente, o compartilhamento discursivo num nível de consciência mais profundo, que não pode ser verbalizado nem descrito. É quando a audiência é fisgada, por exemplo, pelo gesto suspensivo, forte, intenso e ao mesmo tempo enigmático de duende gitano numa boa apresentação de flamenco.

O compartilhamento do discurso ou da mensagem coreográfica não se encerra, assim, numa veiculação unidirecional do aspecto imaginativo-afetivo que supostamente parte do dançarino em direção ao público, pois a sensação inexplicável do arrebatamento estético advém justamente da participação anímica da plateia que retroalimenta o artista. Esse fenômeno sinérgico constitui um fator estético da maior relevância especialmente nas tradições musicais e coreográficas da Ásia Menor, Ásia Central e Oriente Médio, justamente porque qualquer recital e baile ou apresentação é permeado pela lógica do ouvir e dançar "juntos". No ambiente do palco italiano, que definiu a arte cênica ocidental de modo geral, ${ }^{5}$ isso corresponderia à quebra da $4^{a}$ parede, ou parede invisível, que separa plateia e artista, ambientes da recepção e da representação. Quando a dança deixa de ser mimética, no sentido raso do termo, propicia então a experiência efetiva do desvelamento de uma realidade imaginária, mítica ou suprassensorial (Vernant, 1991: 92).

Conceber como real tal experiência imaginária ou mítica, veiculada por um corpo vivente, implica necessariamente na revisão crítica do conceito de mimese, a ser considerado não mais no sentido de cópia mas sim de uma espécie de redescrição ontológico do real (Ricoeur, p. 2005: 373.). 0 corpo certamente pode ter diferentes acepções em diversas perspectivas coreográficas; em termos estéticos (e desta perspectiva), todavia, ele é simultaneamente suporte artístico e natural que se instaura igualmente como metarrefência cultural, histórica e existencial. Uma vez que a dança é uma arte performática efêmera, é sempre e antes de mais nada relativizada pelo próprio corpo dançante, cuja transitoriedade, limites e possibilidades circunscrevem a sua condição de suporte vivo e modelo de significação. A realidade representada (ou desvelada) na dança ganha a existência e a vida inerentes ao corpo dançante no instante fugaz da sua realização. Enquanto o poema se perpetua através dos tempos no papel, letra morta que é revivida e ressignificada na leitura, a dança não é retida pelo traço coreográfico e seu processo vivo desafia o estabelecimento de um sentido unívoco.

\footnotetext{
${ }^{5}$ No palco, onde tradições coreogáficas também costumam ser inventadas pela transposição (Shay, 2002), a dança tem um caráter distinto da sua realização in loco, na qual a relação entre memória, ancestralidade e representação está nitidamente ligada a revivência do mito (Sachs, 1937: 226).
} 
Se tais pressupostos precisam ser explicitados aqui, isso se deve ao fato de que há, por um lado, uma noção generalizada de que a dança pode ser algo belo, porém sem sentido ou significado além da sua dimensão rítmica ou cuja encenação pode ser apreendida e experimentada prioritariamente pelo sentido da visão; por outro lado, diversas teorias da Dança em voga, a maioria delas ocupadas com as expressões artísticas e cênicas, são cindidas e, de forma astuta, cindem também ideologicamente e socialmente as dimensões artística e artesã (ou cultural) da arte dançada (Lopez y Royo, 2008).

\section{Dançando no medievo islâmico}

Do mesmo modo que tais teorias nem sempre são adequadas às diferentes expressões coreográficas orientais da atualidade, para as quais a fronteira entre público e artista não deve ser rigidamente delimitada, não fariam sentido para abordar a noção de dança entre os persas medievais, especialmente os sufis, que compreendiam o corpo como um signo de dupla face, espiritual e natural. Como se faz ainda hoje entre os persas, os místicos e artistas medievais denominam a tal sinergia da dança, bem como da música, de hāl (Alghazali [1058-1111], 1901: 717) - um estado extático sutil, reconhecidamente compartilhado, que teria o poder de elevar a alma e purificar o corpo (Varzi et al, 1986: 3-4).

Nos tempos de um medievo ligeiramente distinto do europeu com o qual estamos habituados pelos vícios escolares do Ocidente, a camada material do corpo, a mais densa, transitória e, provavelmente, diminuta do ser, era descrita nos poemas como uma casca que envolve o miolo; este sim, núcleo luminoso velado por várias outras camadas do ser, não necessariamente individuais como o corpo físico (Bashir, 2011). 0 coração de cada pessoa, como se lê na Sura da Luz (c. 24:35), era facilmente identificado como nicho de um lume no interior daquele miolo, recinto cuja porta se abria à dimensão espiritual e onde as almas, feito feixes de luz que se entrecruzam, poderiam eventualmente experimentar a fusão em pura luz e sentirem-se misteriosamente em comunhão interior e coletiva, tornando-se imediatamente parte de uma essência una e indivisível.

Não obstante, ainda que o fruto, concha ou semente fossem as representações simbólicas mais usuais, concebia-se que as camadas e faculdades anímicas e espirituais, existentes desde antes da criação (Amin, 1991), se sobrepunham interiormente como que de modo convexo mas não necessariamente concêntrico em torno do núcleo corpóreo e poderiam ser contíguas aos elementos aos quais pertenciam. As almas, por exemplo, com frequência eram consideradas simultaneamente espirituais e sensórias, individuais e coletivas; assim, a alma mineral era compartilhada por todos os seres da matéria, porque existia não somente nas rochas que formam as altas e sólidas montanhas, mas também nos minerais que nutrem as ervas e constituem os ossos animais e humanos. A alma vegetal, que dotava de faculdades vegetativas tais como a nutrição, o crescimento e a reprodução, era compartilhada pelos seres nos estágios seguintes, da alma animal e humana; a alma animal, caracterizada pelas faculdades instintivas e pelas emoções, se 
estendia à humanidade, cuja capacidade intelectiva e espiritual, por sua vez, a distinguia e capacitava o homem a integrar os estágios precedentes no nível divino (Avicena [9801037], 2011; Alghazali [1058-1111], 1938). ${ }^{6}$

Dentro dessa cosmologia, a música de afinação natural e microescala cromática vibrava em consonância com os raios estelares e atuava simultaneamente sobre os seres na esfera sublunar, afinando suas dimensões, estágios e faculdades específicas ao momento e tom cósmicos (Michon, 2007). Em resumo, o corpo dançante não se restringia ao humano e não exprimia somente valor estético, mas o efeito espiritual da sinfonia cósmica nos diversos níveis daquele universo em ato, de parido tempo, movimento e matéria simultâneos (Alkindi [séc. IX], 2006). E visto que a dança fosse, pois, signo da criação divina, simbolismo e harmonia eram essenciais à sua plena realização e perfeição.

De modo similar, a poesia mística, enquanto veículo do verbo criador, deveria ressoar no campo da linguagem falada a verdade divina e os mistérios da existência. Ao tecer significações entre natureza referencial e linguagem, o poema estabelecia o vínculo cosmológica entre a palavra e as coisas, cuja essência em comum em termos atributivos e analógicos (Huizinga, 1996: 212-213) e demais correlações simbólicas deveriam estar presentes na espacialidade arquetípica do poema, estabelecido como microcosmo que dispunha imagem e som de forma coesa e coerente com a ideia poética. Porém, uma vez que a estética mística tinha como propósito ultrapassar o plano discursivo para atingir a suprarealidade referenciada pelo poema, propunha paradoxalmente provocar a sua apreensão infusa pela dissipação de todo artifício, de modo a conduzir o ouvinte ao estado de pureza original, próprio da dança e de toda experiência mística: a unidade no Ser.7

\section{Palavra que dança}

Trilhando então o caminho inverso do poético ao corporal - processo que denominamos de metaforização corporal (Yunis, 2013) - constatamos que a metáfora da dança converge da palavra à experiência imaginária do movimento e dali ao campo não verbal da composição poética. É uma espécie de procedimento reverso ao da formulação e comunicação coreográfica. Depende, sobretudo, de como se estruturam os elementos característicos do movimento poético - tais como transições, ritmo, transferências de sentido - que nos parecem compor o fator dançante, responsável por exprimir a particular relação cósmica entre palavra e movimento. Seu domínio abrangeria o trânsito entre a significação poética e a estrutura sígnica, seja em termos metafóricos, de referência coreográfica, seja em

\footnotetext{
${ }^{6}$ A noção difundida por Avicena está baseado no De Anima de Aristóteles, incorporado pela maioria dos filósofos e místicos como representação do mundo. 0 filósofo místico Alghazali, embora critique Avicena, utiliza o mesmo esquema adicionando, porém, a ideia de que além de corpo, alma, espírito e intelecto, o ser humano também está envolto ou é infundido por uma substância essencial etérea que é responsável por sua vida e movimento.

${ }^{7} \mathrm{Na}$ linguagem muçulmana trata-se do tawhīd: no sentido esotérico, a união interna com Deus; no exotérico, a união com a comunidade, comunhão.
} 
termos compositivos, isto é, de uma coreologia poética propriamente dita, concebendo-se a dança, tal como a música, um fator inerente à poesia (Pound, 2006: 22). ${ }^{8}$

Pode-se supor, como fizemos outrora, que esse traço coreológico deva estar relacionado ao aspecto lúdico; segundo Huizinga (1971: 157), encontra-se basicamente no ritmo, que não é somente musical ou métrico, mas jogo de contrastes, oposições, inversões e diálogos e na fonte geratriz da poesia, da dança e do jogo social, cujos traços fundamentais seriam a beleza, o caráter sagrado e a magia. Com efeito, a poesia mística sufi medieval, com seu valor calcado na estética do sublime e do inefável, tem por traço distintivo o jogo entre a fixação rítmica e a variação imagética que leva, paradoxalmente, à dissolução do sentido poético em construção.

Segundo a noção medieval persa da poesia, são as imagens e os verbos metafóricos que unificam temas e aproximam ideias, dotando o poema de coerência e organicidade através da unidade imagética, temática e sonora, cuja trama espacial e semântica se entrelaça em antíteses, transições, condensações, recursos da sonoridade e divisões temático-espaciais (Meisami, 2003: 390). Essa espécie de suprametáfora constitui uma rede de significação que integra também argumentos filosóficos, símbolos e alegorias a partir da estrutura do symbolon.

O symbolon consiste numa fórmula silogística que combina símbolos de caráter mitopoético, empréstimos metafóricos e predicados argumentativos, sendo que o seu uso alusivo (išārah) em citações religiosas, filosóficas ou literárias, estrutura-se como interface discursiva, ao modo da metáfora metafísica. Assim, por exemplo, a imagem da rosa, signo místico da experiência corporal na existência terrena, pode também aludir a um capítulo ou ideia moral do Jardim das Rosas de Sa'di [1184-1291] (2000); bem como pássaros aos pássaros ou à mariposa noturna da Linguagem dos pássaros de 'Attār [1145-1221] (1991) e assim por diante. Além disso, tais imagens possuem denotação simultaneamente dramático-coreográfica, teosófica e proverbial na tradição persa.

Além dessa estrutura metafórica de base, extensível ao referente simbólico ou intertextual e que funde o modo afetivo à ideia abstrata, a sintaxe persa possibilita uma dinamicidade muito peculiar à significância poética. Por um lado, facilita a polissemia do enunciado e, por outro, situa o verbo ao final da frase (Hooshang, 2007), o que permite que a rede imagética, construída verso a verso, seja axializada pelo verbo metafórico em anáfora, cujo paralelismo espiralado não apenas compara mas desdobra os versos uns sobre os outros, gerando uma instabilidade constante dos predicados (Yunis, 2013: 4963). É precisamente essa movência permanente que leva ao esfacelamento do sentido verbal e à experimentação do dançável naquela poesia.

Para transpor minimamente este traço compositivo da significância (Laranjeira, 2003), a tradução deve marcar de forma mais aproximada possível a espacialização dos elementos imagéticos com o ritmo, delimitando o hemistíquio pelo padrão rítmico, integrando os pés métricos aos sintagmas semânticos e encerrando a sentença com a

\footnotetext{
${ }^{8}$ Pound abre seu estudo sobre literatura afirmando que "a música começa a se atrofiar quando se afasta da dança e a poesia quando se afasta da música”. Tradução de Augusto de Campos e José Paulo Paes.
} 
rima, que não raro está construída a partir do verbo. No caso do gazal persa, que é uma forma-poema curta, condensada da qasida árabe e de uso liricomusical, há também a sobreposição contígua de tópicos a cada dois ou três versos para fundir temas; no caso da poesia mística, especialmente os báquico, amoroso e espiritual.

\section{Traduzindo o gazal dançante de Rumi}

Há mais de 35 mil versos no Divan de Shams de Tabriz, entre rubais, poemas estróficos e gazais, a maioria deles tendo em média de 5 a 12 versos ou um pouco mais, como o gazal 2131 (numerado conforme a edição crítica de Badi Uzaman Foruzanfar Rumi [1207-1273], 1957), para o qual se apresenta a seguir um exercício de tradução inédita e direta do persa para o português:

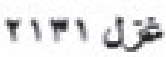

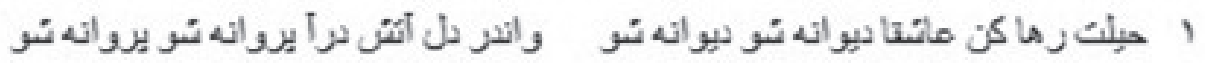

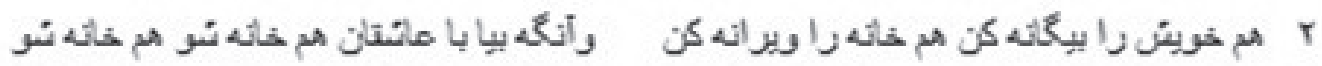

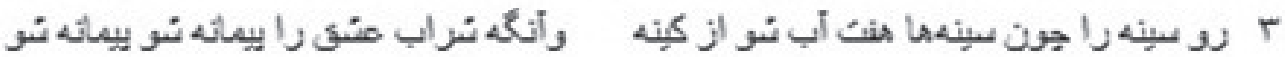

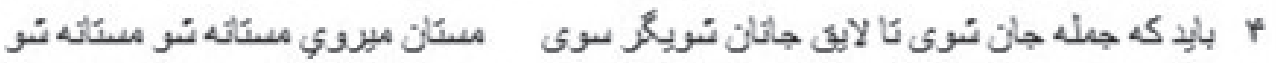

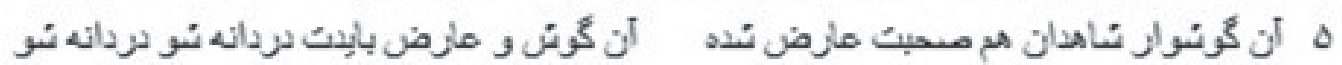

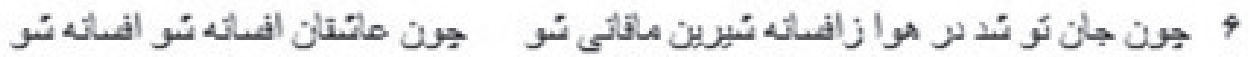

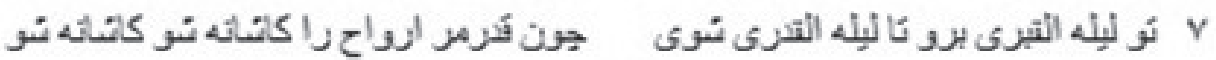

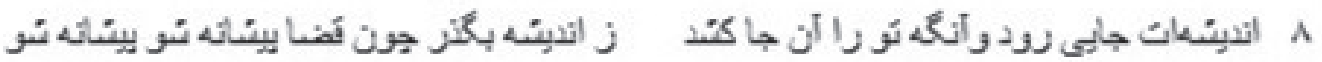

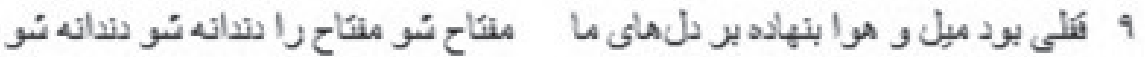

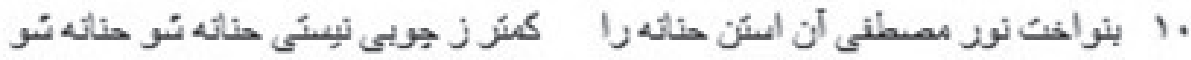

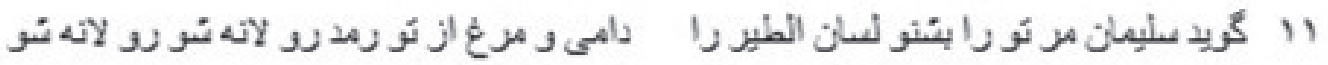

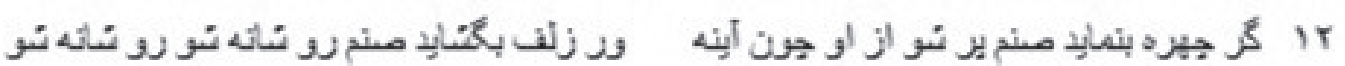

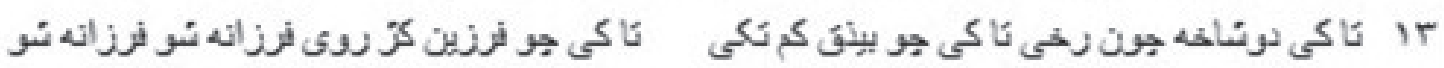

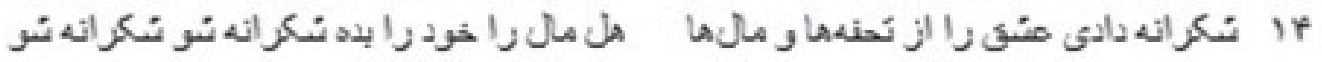

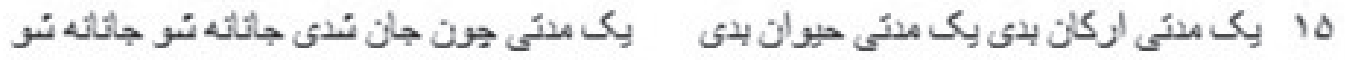

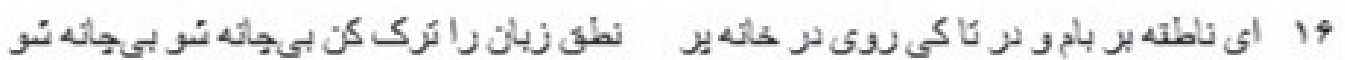




\section{GAZAL 3121 - Mariposa torna-te}

1 Deixa de jogo, amante! louco torna-te. No coração do fogo, mariposa torna-te,

louco torna-te mariposa torna-te

2 Faz-te estrangeiro e da casa, ruinas; dos amantes, hóspede torna-te hóspede torna-te

3 Em sete águas, limpa-te da raiva; do Amor, bebe o vinho; cálice torna-te

cálice torna-te

4 Purifica-te, sê digno dos puros; seguin do os embriagados, embriagado torna-te embriagado torna-te

5 Ouvir visionários é ser conta no colar. Veja e ouça, madrepér ola torna-te madrepér ol a torna-te

6 Se te elevam as doces fábulas aniquila-te como os am antes, fábula torna-te fábula torna-te

7 Na noturna sepultura, tua noite de poder.

Sê magn ânimo, morada torna-te morada torna-te

8 Teu pensar é rio de fortes correntezas. Lidera o pensamento, lider torna-te lider torna-te

9 A vontade, cadeado em nossos corações. chave torna-te e desta segredo torna-te segredo torna-te

$10 \mathrm{O}$ pilar irradia a luz de Mustafá. Não és inferior à madeira, compassivo torna-te compassivo torna-te

11 Salomão te en sinou a lingua dos pássaros, se debandam do prado, ninho torna-te ninh o torna-te

$12 \mathrm{Se}$ o idolo mostra a face, espelho torna-te libera-lhe os cachos, pente torna-te pente torna-te

13 Até quando jogar: baixo peão, retida torre, obliqua rainha? Do xadrez, mestre torna-te mestre torna-te

14 Grato, presenteias teu amor. Lança bens e a ti mesmo, gratidăo torna-te gratidão torna-te

15 És misto: Elemental, animal e alma. Alma de alma, par da alma torna-te par da alma torna-te

16 Até quando tagar elar por dentro? Deixa de especulação. Silente torna-te 
Mesmo através de um breve golpe de vista, pode-se observar as analogias que se buscou estabelecer entre tradução e original: uma sintaxe particular, estrutura bipartida do verso, divisão temático-espacial das seções e, ainda que em detrimento da precisão rítmica, destaque da rima anáfora e sua repetição consecutiva em refrão. Já em termos de significação, devemos iniciar pelo verso de abertura, por seu caráter introdutório que, de praxe, indica o propósito e o efeito almejado com o poema: fazer o ouvinte entrar no coração do fogo, poetizar-se/ tornar-se louco (dīvān-e šō). Trata-se do gatilho da audição mística, que deve fazer do ouvinte uma pérola-única (traduzimos como madrepérola), ou seja, uma testemunha direta da realidade poética. A audição deve ser como o 'pente' que desembaraça as mechas (tropo metarreferencial da poesia), em que o ouvinte irá desvelar os aspectos formais e semânticos da composição para ultrapassar e dissolver dentro de si as ilusões projetivas que o artifício poético instiga. Mais do que escutar ou saber a linguagem dos pássaros (espíritos), a audição requer a receptividade do autossacrifício, da gratidão despojada, do abandono do jogo e da serenidade silenciosa que apontam para uma atitude contemplativa.

Quase todos os versos apresentam uma relação contrastante ou comparativa entre o primeiro e o segundo hemistíquios, em que a ação metafórica empresta o sentido cinético e qualitativo das imagens tanto por meio de analogia (tamtīl) - preponderante nos versos 3, 5, 7, 10, 12, 13 e 16 - quanto da similaridade (tašbīh) - preponderante nos versos $1,2,4,6,8,9,11,14,15$. As ações revelam duas tônicas principais: receptividade interna (ninho, morada, hóspede, par) e movimento (pérola, chave, pente, aves, seguir, jogar) que, quando circulatório ou giratório, designa perfeição em oposição à incongruência e assimetria (rebaixamento, obliquidade, rigidez).

$\mathrm{Na}$ unidade extensional do verso, verificamos uma divisão quadripartite dos tipos de predicados verbais que seguem, via de regra, a seguinte ordem: passivo, reativo, transitivo e transformativo; na última seção, repete-se no modo do refrão persa (radīf) a rima anáfora, formada pelo substantivo + sufixo predicativo (eh) e o verbo cópula ser/ estar/existir (būdan) no imperativo (šō). Traduzível por ser (como tal coisa), o verbo em função auxiliar transforma substantivos em verbos e tem sua ênfase na ação transmutadora, passando a constituir o verbo cópula tornar-se. Tornar-se não corresponde somente a ser como, mas ao paradoxo metafórico de ser e não ser, cuja transmutação de sentido ao longo de todo o poema refere-se aos predicativos nos quais o destinatário do poema deve tornar-se, vir à ser.

No modo imperativo, o verbo metafórico da rima possui caráter enfático, mas a sua repetição pelo refrão persa gera um certo esvaziamento, pois produz o efeito combinado do conjuro e do eco hipnótico. Tal efeito induz à interatividade imaginária do ouvinte, que participa ativamente da construção metafórica ao transformar-se imaginariamente nas imagens e, passando de uma a outra, transmutar-se a si mesmo: a mariposa (signo do louco e do poeta) dança em torno da chama, torna-se hóspede, companheira, embriagada, pérola (alma integrada e visionária), fábula (esfacelada do eu), morada, guia, chave, compaixão, ninho (dos seres celestiais), pente (da imaginação e do poema), mestre, gratidão, alma (da 
pureza) e, por fim, silenciosa (serena). A rima em refrão, que constitui o centro para onde converge toda significação poética, transforma e 'queima' tudo em seu paralelismo léxico e semântico. É, de certa forma, um não lugar: campo vertiginoso da mutação metafórica e mística onde podemos situar arquetipicamente a fogueira, o coração do poema.

Neste tipo singular de paralelismo os versos se sobrepõem uns aos outros como se girássemos o papel em que estão escritos e construíssemos assim um cone: forma geométrica da espiral de ouro que rege a órbita das galáxias, o fluxo das águas, o crescimento das conchas e das plantas; o movimento das fibras musculares e da inflorescência das rosas, que desde o século XII se calcula pela sequência Fibonacci, cuja fórmula converge aproximadamente à da proporção áurea (Prusinkiewicz e Lindemayer, 1990: 101-107). Tal giro é que configura a forma arquetípica da estrutura metafórica: espiral de fogo, de vinho e de rosa. Gesto conexo ao coração. Passo de saber experiencial na existência corpórea.

\section{Por fim}

O tipo de análise realizado envolveu uma espécie de gestalt que só posteriormente conseguimos elucidar. Inicialmente, detectamos qualidades cinéticas nas imagens a partir de sua representação coreográfica na tradição persa, não necessariamente de origem sufi. É preciso considerar, porém, conforme já se sugere a respeito do caráter interativo daquela metáfora, que há uma mutação interna relacionada à recepção do poema como um todo, tanto através do ouvir e do imaginar quanto do processo tácito da formulação metafórica que, como prevê a teoria cognitiva, é também corporal. Esse jogo entre a apreensão verbal e não verbal da metaforização corporal é o que caracteriza o aspecto propriamente lúdico da metáfora da dança.

Concluímos, então, que essa apreensão lúdica do poema místico se realiza na medida em que a poesia também carrega traços coreológicos, não somente em imagens de uso cinético (passos) ou extracinético (símbolos), mas indicações de atitudes e estados anímicos pelos quais o processo de significação se torna intercambiável entre ambas as linguagens: o movimento dando sentido à palavra e vice-versa. Partindo da noção silogística dos persas e de seu uso do symbolon para construir valor simultaneamente estético e filosófico, reconhecemos na imagem mitopoetica da dança uma metaforicidade desestabilizadora, porque conduz à experiência silenciosa do sensorial infuso e beira a ausência de discurso, típica do dançado. Com importantes implicações linguísticas e filosóficas, consideramos a imagem da dança uma metáfora metafísica de apropriação e interdiscursiva (Ricoeur, 2005: 444-445); mais do que isso, se nos afigurou como a metáfora das metáforas por ser a metáfora do Ser em ato. ${ }^{9}$

\footnotetext{
${ }^{9}$ A metáfora aristotélica que faz imagem tem para Ricoeur a função ontológica de redescrever o Real porque "apresentar os homens "agindo" e todas as coisas "como em ato" e tal seria a função ontológica do discurso metafórico, no qual "toda a potencialidade adormecida da existência parece como eclodindo, toda capacidade latente de ação, como efetiva" (Ricoeur, 2005: 75).
} 
Avançada nossa pesquisa, hoje compreendemos que a metáfora metafísica pressupõe a divisão físico-espiritual; portanto, a metáfora da dança em Rumi, por sua polivalência e tendência apofática, vai além e é antes metáfora mística no sentido mais elevado. Através da sua estrutura metafórica peculiar, corpo dançante e poema se tornam índices ontológicos da revalidação do pacto primordial, restaurando o suprarreal onde sentidos e intelecto são insuficientes e desintegrados. Dançar é poetizar a si mesmo e, como ensina Rumi, o seu mistério se acessa por uma via: poetiza-te e entra no coração do fogo.

\section{Bibliografia}

ALGHAZALI, 1058-1111. "The explanation of the Wonders of the heart". Connecticut/ USA: Hartford Seminary Foundation, 1938. Tradução de Walter James Skellie.

"Emotional religion in islam as affected by music and singing" In Journal of the Royal Asiatic Society of Great Britain and Ireland, v. 33, parte I - pp.195-252, parte II - 705-748. London: Royal Asiatic Society, 1901. Tradução de Duncan Black McDonald do capítulo oitavo da obra original: Ihya' Ulum ad-Din.

ALKINDI, séc. IX. "A Filosofia Primeira" In Tiraz Revista de Estudos Árabes e das Culturas do Oriente Médio. São Paulo: FFLCH/USP, pp. 129-159, 2006. Tradução, introdução e notas por Miguel Attie Filho e Safa Alfred Chahla Jubran. Texto bilingue árabe-português.

AMIN, W. M. A. B. An Evaluation of the Qut al-Qulub of al-Makki with an Annoted Translation of his Kitab al-Tawba. PhD Thesis, University of Edinburgh, Escócia, 1991.

ATTAR, 1145-1221. A linguagem dos pássaros. São Paulo: Attar editorial. Tradução da versão francesa de Garcin de Tassy de Álvaro de Souza Machado e Sergio Rizek, 1991.

AVICENA, 980-1037. Livro da Alma. São Paulo: Globo, 2011. Tradução Miguel Attie Filho.

BASHIR, Shahzad. Sufi bodies: Religion and Society em Medieval Islam. Nova York: Columbia University Press, 2011.

GIBBS, Raymond e WILSON, Nicole. "Real and Imagined Body Movement Primes Metaphor Comprehension.” In: Cognitive Science, Santa Cruz: University of California, n. 31 , pp. 721-731, 2007.

GUILHON, Giselle. Rumi e Shams (notas biográficas). São Paulo: Fonte Editorial, 2015.

HANNA, Judith Lynne. To dance is human. Chicago: University Chicago Press, 1979.

HOOSHANG, Saied. Persa para españoles. Madrid: Ediciones Clásicas, 2007.

HUIZINGA, Johan. Homo Ludens: o jogo como elemento da cultura. São Paulo: Perspectiva, 1971. Tradução de João Paulo Monteiro.

HUIZINGA, Johan. O declínio da Idade Média. Braga: Editora Ulisseia, 1996. 
LARANJEIRA, Mario. Poética da Tradução: Do sentido à significância. São Paulo, Edusp, 2003.

LOPEZ y ROYO, Alessandra. ReConstructing and RePresenting dance: Exploring the dance/ archaeology conjunction. Stanford: Stanford University, 2008.

MEISAMI, Julie Scott. Structure and Meaning in Medieval Arabic and Persian Lyric Poetry Orient Pearls. London: Routledge, 2003.

MICHON, Jean Louis. "Music and Spirituality in Islam” In: CORNELL, V. J (ed.) Voices of Islam - Voices of Arte, Beauty, and Science. Westport: USA: Praeger Publishers, v.4, pp. 5888, 2007.

POUND, Ezra. Abc da Literatura, São Paulo: Cultrix, 2006. Tradução Augusto de Campos e José Paulo Paes.

PRUSINKIEWICZ, P. e LINDENMAYER, A. The Algorithmic Beauty of Plants. New York: Springer-Verlag, 1990.

RICOEUR, Paul. A metáfora viva. São Paulo: Edições Loyola, 2005. Leituras Filosóficas. Tradução de Dion Davi Macedo.

RUMI, Jalal Uddin, 1207-1273. Kulliāt-i Shams yā Dīwān-i Kabīr. Teheran: Amir Kabîr, 1957. Edição de Badî‘ Al-Zamân Furûzanfar.

The Mathnavi of Jalaluddin Rumi. London: Luzac, 1940. E. J. W. Gibb Memorial Series. Versão bilingue persa/inglês com tradução de Reynold Alleyne Nicholson.

SA'DĪ, 1184-1291. O Jardim das Rosas. São Paulo: Attar Editorial, 2000. Tradução de Rosângela Tibúrcio, Beatriz Vieira e Sergio Rizek.

SACHS, Curt. The evolution to the spectacular dance and the oriental civilizations. World history of the dance. New York: Vail-ballou Press, 1937.

SHAY, Anthony. Choreographic Politics: State Folk Dance Companies, Representation, and Power. California: Wesleyan University Press, 2002.

TEIXEIRA, Faustino. "A flama do coração: Perspectivas em Rumi" In LUCCHESI, Marco (Org.). A Flauta e a Lua. Rio de Janeiro: Bazar do Tempo, 2016.

TRADUÇÃO DO SENTIDO DO NOBRE CORÃO PARA A LÍNGUA PORTUGUESA realizada por Dr. Helmi Nasr, professor de Estudos Árabes e Islâmicos na Universidade de São Paulo, Brasil, com a colaboração da Liga Islâmica Mundial, Meca/Medina/Brasil, impresso no Complexo do Rei Fahd, Al Munauarah K.S.A.

VARZI, Ostad Mortezâ, CATON, Margaret, FRIEND, Robyn C. Friend e SIEGEL, Neil. "Performer-Audience Relationships in the Bazm" In Anais de The Middle East Studies Association, Boston, Massachusetts: Institute of Persian Performing Arts, novembro de 1986. Disponível em: http://home.earthlink.net/ rcfriend/robyn12.htm, acesso em 04/11/2016. 
artigo

VERNANT, Jean-Pierre. "O sujeito trágico: historicidade e trans-historicidade" In: VERNANT, Jean-Pierre e VIDAL-NAQUET, Pierre (orgs.) Mito e tragédia da Grécia Antiga, v. II. São Paulo: Brasiliense, 1991.

WILLIAMS, Drid. Ten lectures on theories of the dance. USA: Paperbook, 2004.

Texto recebido em: 03 de Março de 2017

Aprovado em: 05 de Maio de 2017 